\title{
MARGINAL REGION MATHEMATICS TEACHERS' PERCEPTION OF USING ICT MEDIA
}

\author{
Trisna Roy Pradipta*1, Krisna Satrio Perbowo', Afifah Nafis ${ }^{1}$, Asih Miatun ${ }^{1}$, Sue Johnston-Wilder ${ }^{2}$ \\ ${ }^{1}$ Universitas Muhammadiyah Prof. Dr. HAMKA, Indonesia \\ ${ }^{2}$ University of Warwick, England, UK
}

\begin{tabular}{l} 
Article Info \\
\hline Article history: \\
Received Aug 24, 2020 \\
Revised Jan 29, 2021 \\
Accepted Jan 31, 2021 \\
\hline
\end{tabular}

Keywords:

ICT,

Marginal region,

Perception

\begin{abstract}
The article presents a marginal region mathematics teachers' perception of ICT as learning media and the type of ICT media used in mathematics classrooms. A survey was designed including two domains: the usability and the importance of ICT. A questionnaire was administered to 84 mathematics teachers in marginal regions. The respondents were chosen conveniently based on their accessibility and availability. About $50 \%$ of marginal region mathematics teachers do not use ICT in teaching. The most common media used is Microsoft Office software to present teaching materials from internet or digital sources. Using the Rasch model, the data show that mathematics teachers' perception of the usage and importance of ICT as a media of mathematics learning can be categorized as 'medium' level. Mathematics teachers in the marginal regions consider ICT as mathematics learning media to be fairly important.
\end{abstract}

Copyright (C) 2021 IKIP Siliwangi. All rights reserved.

\section{Corresponding Author:}

Trisna Roy Pradipta,

Department of Mathematics Education,

Universitas Muhammadiyah Prof. Dr. Hamka,

Jl. Tanah Merdeka, Pasar Rebo, Jakarta Timur, Jakarta, Indonesia.

Email: troymath@uhamka.ac.id

How to Cite:

Pradipta, T.R., Perbowo, K.S., Nafis, A., Miatun, A., \& Johnston-Wilder, S. (2021). Marginal region mathematics teachers' perception of using ICT media. Infinity, 10(1), 133-148.

\section{INTRODUCTION}

Only a few published articles were found talking about mathematics education in marginalised contexts (Howley, Howley, \& Huber, 2005). It means, more attentions are needed to improve the quality of mathematics education in marginal regions. More collaboration is needed, both practically and academically, in mathematics education in marginal contexts (Bush, 2005; Nicol, Archibald, \& Baker, 2013). A small part to contribute in solving mathematics education issue in the marginal region is to depict mathematics teachers' perception of using ICT as learning media in their classroom.

Learning media is a tool to deliver learning information that is designed so that it can help students understand the subject (Muhson, 2010), as well as a communication tool for interaction between teachers and students in the learning process (Ahern, 2016). The purpose of learning media use is to stimulate the mind and attention of students (Triyanto, Anitah, \& Suryani, 2013). While, the function of learning media is to accelerate the learning process effectively, improve quality and concretise abstract material (Nurseto, 2011). The use of 
varied and innovative learning media can increase the joy and love of learning mathematics (Safitri, Hartono, \& Somakim, 2013). The rapid development of technology in the modern age has become the latest innovation in the learning process. ICT media is one of the learning media besides teaching aids that are often used in learning mathematics.

The rapid development of technology has an impact on the world of education, creating expectations to integrate ICT into the classroom; this can change conventional learning styles (directs-teaching \& learning) into constructivist learning (Donnelly, McGarr, \& O'Reilly, 2011; Hismanoglu, 2012; Lin, Wang, \& Lin, 2012; Smith, Shin, \& Kim, 2017). ICT-assisted learning is an effective and efficient way of building knowledge so that it helps teachers create a modern learning context (Eyyam \& Yaratan, 2014). Learning by involving ICT can facilitate students in understanding concepts in theoretical and practical approaches by using technology such as LED TV, LCD Projectors, Laptops, Tablets, Computers, Mobile Phones, Internet, etc. (Gautam \& Agrawal, 2012). The forms of ICT media used in the learning process are text, audio, video or images (Blum \& Parette, 2015). ICT plays the most important factor in creating enjoyable and efficient learning to achieve learning effectiveness so that it can improve learning outcomes. ICT media software in learning mathematics includes Geogebra, Sketchpad, Microsoft Mathematic, Autograph, and others (Bakar, Ayub, \& Tarmizi, 2010). Learning via the internet is rampant nowadays (Limayem \& Cheung, 2011) because the internet is a place of learning to obtain information and knowledge anywhere and anytime, following various forms of media via the internet such as Ruang Guru, Zenius, Youtube, Brainly, and Edmodo. There are many benefits obtained by using ICT (Ali, Haolader, \& Muhammad, 2013), most teachers recognise the importance of using ICT in learning so training is needed so that teachers can integrate ICT effectively in the teaching and learning process.

ICT becomes one of the important factors in a country's development process depending on the readiness of infrastructure and the spread of ICT (Alghamdi, Goodwin, \& Rampersad, 2011). In Indonesia, the progress of ICT has developed rapidly. The Tim Indikator TIK Pusat Litbang PPI (2015) surveyed conditions within households, in Indonesia, with the use of ICT as follows: (1) have computers in urban regions $41.9 \%$ while rural $19.9 \%$ (2) use the internet in urban regions $47.9 \%$ while rural $24.7 \%$ (3) have mobile phones in urban regions $90.9 \%$ while rural $78.8 \%$. Based on the survey results, the use of ICT was still relatively low in rural regions compared to urban regions. This finding has been supported by several studies; ICT can be experienced throughout Indonesia. Amin (2016) found the use of the internet in the education sector in the eastern border region using mobile broadband is as much as $50.4 \%$, while $40.2 \%$ of schools are using fixed broadband. Based on the Ministry Performance Report (Afidah, Doom, \& Putri, 2017), a strategy for the availability of ICT infrastructure and the development of ICT ecosystems has been worked with villages in the border areas, disadvantaged areas, including local transportation services available in $4.02 \%$ of 222 locations and 3 piloting villages. The development of ICT in the marginal regions is one of the active missions carried out by the Ministry of Research and Technology since 2000 among others in the form of Warung Informasi dan Teknologi (Warintek), Community Access Points (CAP), and Mobil Pusat Layanan Internet Kecamatan (MPLIK), which by 2013 had a number of 84 stalls scattered in 28 of 34 provinces in Indonesia (Kusnandar, 2013). All statements above show that only some marginal regions are occupied with information and technology services.

However, the use of ICT as a learning media in marginal regions has not been realised comprehensively in almost schools in Indonesia. This is because human resources and marginal region governance have not contributed fully in the context of developing their regions (Chaerul \& Aisyah, 2014), so that there are many limitations of facilities and infrastructure owned by marginal regions including the difficulty of getting access to basic 
services, such as education, health, water, infrastructure, transportation, electricity, and telecommunications (Kementerian PPN/Bappenas, 2016). Despite the problems of the marginal regions, there are very few marginal regions that have experienced the use of ICT.

Limited access to ICT in marginal areas raises a question about mathematics teachers' perception of the use of ICT media in learning mathematics in marginal regions.

\section{METHOD}

This research was conducted by a survey with a quantitative descriptive approach. Data were collected by a questionnaire adapted and translated from Albalaw (2017). The questionnaire was translated and checked by an expert from English Department of University of Muhammadiyah Prof. Dr. HAMKA, Indonesia. The instrument contained statements of perception of mathematics teachers toward the use of ICT. It consists of two domains or variables: the use of ICT as a learning media (19 items) and the importance of ICT as a learning media (27 items). The validity and reliability of the instrument were checked with the Rasch model. The instrument is valid due to the high PTMEA CORR score for each item ( $x>0.2$ ), and Raw-variance more than $40 \%$ and Unexplained-variance less than $15 \%$ for each domain (Linacre, 2011). The reliability of the instrument is high with Person reliability 0.93, Item reliability 0.98 and Alpha Cronbach 0.98 (Bond, Yan, \& Heene, 2020). Data from the questionnaire were processed using the Rasch model assisted with Winstep application to convert ordinal data into interval data (Sumintono \& Widhiarso, 2014). The respondent perception and the item responses are represented on the Wright map $\operatorname{logit}(\log$ odds unit) scale such as those given in Figure 1 and Figure 2. The results of respondents' responses are converted into the form of measure scale values with standard deviation calculations so that each domain has a different scale as seen in Table 1.

Table 1. Item logit categories

\begin{tabular}{cccc}
\hline \multicolumn{2}{c}{ Domain 1: The Use of ICT } & \multicolumn{2}{c}{ Domain 2: The Importance of ICT } \\
\hline Mean measure range & Decision & Mean measure range & Decision \\
\hline $0.765<x$ & Never existed & $0.75<x$ & Unimportant \\
$0.255<x \leq 0.765$ & Rarely & $0.25<x \leq 0.75$ & Fairly Important \\
$-0.255<x \leq 0.255$ & Sometimes & $-0.25<x \leq 0.25$ & Somewhat Important \\
$-0.765<x \leq-0.255$ & Mostly & $-0.75<x \leq-0.25$ & Important \\
$x \leq-0.765$ & Always & $x \leq-0.75$ & Very Important \\
\hline
\end{tabular}

Due to the limitation to reach population of mathematics teachers in marginal regions of Indonesia, this research was using convenience sampling that consisted of 84 mathematics teacher respondents in the marginal regions with levels of schools ranging from elementary (D), junior high (P), to high school (A) spread from western to eastern Indonesia; the number of respondents in each region can be seen in Table 2. The geographical locations in western Indonesia include Sumatra, Java, Kalimantan, and Bali Province. Geographical locations in eastern Indonesia include Sulawesi Island, Maluku Province, West Nusa Tenggara Province, East Nusa Tenggara Province, and Papua Island. 
Table 2. Grouping data based on respondent geographical location and level of school

\begin{tabular}{ccccc}
\hline \multirow{2}{*}{ Geographical Location } & \multicolumn{3}{c}{ Level } & \multirow{2}{*}{ Total } \\
\cline { 2 - 4 } & D & P & A & \\
\hline East & 2 & 24 & 8 & 34 \\
West & 27 & 17 & 6 & 50 \\
\hline Total & 29 & 41 & 14 & 84 \\
\hline
\end{tabular}

\section{RESULTS AND DISCUSSION}

\subsection{Results}

\subsubsection{Types of ICT as a learning media}

The type of ICT used in mathematics learning activities in marginal regions based on geographical location in Table 3 shows that Microsoft Office is most used in western Indonesia with 11 people compared to eastern Indonesia with four people with a percentage of $17.86 \%$ users. This is different from eastern Indonesia, where the type of ICT media most used is mathematics software with a total of 8 people while in western Indonesia there are 5 people with a percentage of users of $15.48 \%$. However, there are still many mathematics teachers in marginal areas who did not use ICT media in mathematics learning, with a percentage of $50.00 \%$ of the total respondents. The majority of marginal regions mathematics teachers are not using any ICT or even digital media during teaching mathematics. This seems due to the constraint of facility and communication access.

Table 3. Types of ICT media based on geographical location

\begin{tabular}{|c|c|c|c|c|}
\hline \multirow{2}{*}{ Media } & \multicolumn{2}{|c|}{ Location } & \multirow{2}{*}{ Total } & \multirow{2}{*}{ Percentage } \\
\hline & East & West & & \\
\hline Electronic Book & 1 & 0 & 1 & $1.19 \%$ \\
\hline Social Media & 0 & 2 & 2 & $2.38 \%$ \\
\hline Microsoft Office & 4 & 11 & 15 & $17.86 \%$ \\
\hline Online Media & 3 & 8 & 11 & $13.10 \%$ \\
\hline Mathematics Software & 8 & 5 & 13 & $15.48 \%$ \\
\hline Not using & 18 & 24 & 42 & $50.00 \%$ \\
\hline Total & 34 & 50 & 84 & $100.00 \%$ \\
\hline
\end{tabular}

The most common media used within the regions is Microsoft Office, especially in the western part of Indonesia. The teachers use PowerPoint to present their works, or they use Word to show the teaching materials they wrote or took from internet/digital sources to their students. Meanwhile, mathematics software is more prevalent in eastern Indonesia.

The type of ICT based on the Level of Education used in learning mathematics in the marginal regions in Table 4 shows that the use of ICT media in mathematics learning for the elementary school level (D) is widely used, namely six people use online media. For the junior high school level (P), the use of ICT media which is widely used in learning mathematics is mathematics software, as many as 10 out of 13 users. Whereas for the high school level (A) there are two ICT media which are widely used in mathematics learning, as many as 3 out of 15 users of Microsoft Office and 13 users of mathematics software. 
Table 4. Types of ICT Media based on School Levels

\begin{tabular}{|c|c|c|c|c|c|}
\hline \multirow{2}{*}{ Media } & \multicolumn{3}{|c|}{ Level Education } & \multirow{2}{*}{ Total } & \multirow{2}{*}{ Percentage } \\
\hline & D & $\mathbf{P}$ & $\mathbf{A}$ & & \\
\hline Electronic Book & 0 & 1 & 0 & 1 & $1.19 \%$ \\
\hline Social Media & 1 & 1 & 0 & 2 & $2.38 \%$ \\
\hline Microsoft Office & 4 & 8 & 3 & 15 & $17.86 \%$ \\
\hline Online Media & 6 & 4 & 1 & 11 & $13.10 \%$ \\
\hline Mathematics Software & 0 & 10 & 3 & 13 & $15.48 \%$ \\
\hline Not using & 18 & 17 & 7 & 42 & $50.00 \%$ \\
\hline Total & 29 & 41 & 14 & 84 & $100.00 \%$ \\
\hline
\end{tabular}

The types of ICT used in mathematics learning are grouped based on geographical location and education levels in Table 5. It can be seen that the ICT media that are widely used in western Indonesia are online media with 6 users found in D. While for eastern Indonesia, Mathematics software is most widely used with 6 users in P.

Table 5. Types of ICT Media based on Geographical Location and School Level

\begin{tabular}{lccccccc}
\hline \multirow{2}{*}{ Media ICT } & \multicolumn{3}{c}{ East } & \multicolumn{3}{c}{ West } & \multirow{2}{*}{ Total } \\
\cline { 2 - 6 } & D & P & A & D & P & A & \\
\hline Electronic Book & 0 & 1 & 0 & 0 & 0 & 0 & 1 \\
Media Social & 0 & 0 & 0 & 1 & 1 & 0 & 2 \\
Microsoft Office & 0 & 3 & 1 & 4 & 5 & 2 & 15 \\
Online Media & 0 & 3 & 0 & 6 & 1 & 1 & 11 \\
Mathematics Software & 0 & 6 & 2 & 0 & 4 & 1 & 13 \\
Not using & 2 & 11 & 5 & 16 & 6 & 2 & 42 \\
\hline \multicolumn{1}{c}{ Total } & 2 & 24 & 8 & 27 & 17 & 6 & 84 \\
\hline
\end{tabular}

\subsubsection{The usage of ICT as a learning media}

The questionnaire data distribution consisted of 19 items of statements regarding the use of ICT as a learning media. The variable map in Figure 1 shows the item that was most difficult to be agreed upon by respondents is item number 6. In comparison, the items that were most approved were item numbers 17 and 3. 


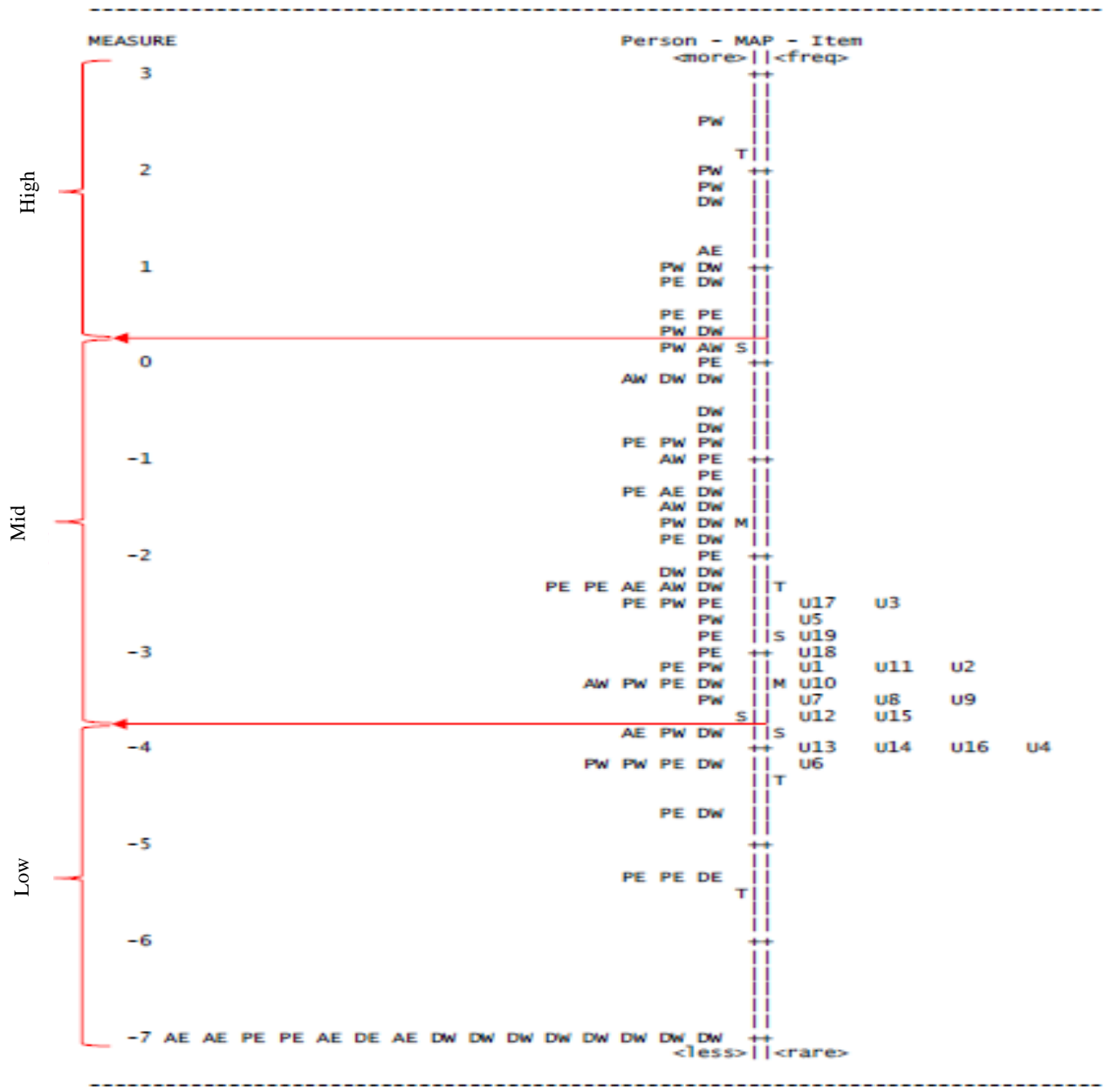

Figure 1. Variable map of the use of ICT as a learning media

Table 6 shows the logit standard deviation values according to the item logit category of respondents' responses in Table 1 . From Table 6, it is known that there are six items in the category of 'rarely' use (Numbers: 4, 6, 12, 13, 14 and 16). While the 'always' usage category contained three items (No: 3, 5 and 17). In addition, it can be seen that there are 14 items that are categorised as 'rarely' and 'sometimes' and five items that are categorised as 'always' and 'mostly'.

Table 6. Domain 1: The use of ICT as a learning media

\begin{tabular}{clcc}
\hline No & \multicolumn{1}{c}{ Items } & Logit Value & Most Responses \\
\hline 1. & $\begin{array}{l}\text { I use ICT as one of my methods in teaching } \\
\text { mathematics }\end{array}$ & -0.17 & Sometimes \\
2. $\quad \begin{array}{l}\text { I give students my social media contact } \\
\text { information at the beginning of the semester }\end{array}$ & -0.17 & Sometimes \\
3. $\quad \begin{array}{l}\text { I encourage students to learn mathematics } \\
\text { through ICT }\end{array}$ & -0.83 & Always \\
4. $\quad \begin{array}{l}\text { I encourage students to follow an online } \\
\text { learning forum }\end{array}$ & 0.60 & Always \\
5. $\quad \begin{array}{l}\text { I give students an idea about the necessary } \\
\text { websites and apps for learning mathematics }\end{array}$ & -0.77 & \\
\hline
\end{tabular}




\begin{tabular}{|c|c|c|c|}
\hline No & Items & Logit Value & Most Responses \\
\hline 6. & $\begin{array}{l}\text { I recognise students' academic improvement } \\
\text { through ICT }\end{array}$ & 0.71 & Rarely \\
\hline 7. & $\begin{array}{l}\text { By the use of ICT, I implement the concept of } \\
\text { cooperative learning }\end{array}$ & 0.15 & Sometimes \\
\hline 8. & $\begin{array}{l}\text { I deliver the content of the courses to my } \\
\text { students through ICT }\end{array}$ & 0.19 & Sometimes \\
\hline 9. & $\begin{array}{l}\text { I give students a chance to cooperate learning } \\
\text { through the use of ICT }\end{array}$ & 0.06 & Sometimes \\
\hline 10. & I solve students' learning problems through ICT & -0.04 & Sometimes \\
\hline 11. & I teach some parts of the math course using ICT & -0.23 & Sometimes \\
\hline 12. & $\begin{array}{l}\text { I give students extra-curricular activities } \\
\text { assigned through ICT }\end{array}$ & 0.32 & Rarely \\
\hline 13. & $\begin{array}{l}\text { I assign students in groups to discuss and solve } \\
\text { math problems through ICT }\end{array}$ & 0.57 & Rarely \\
\hline 14. & $\begin{array}{l}\text { I prepare quizzes for students and tell them to } \\
\text { do it through ICT }\end{array}$ & 0.64 & Rarely \\
\hline 15. & I design courses using ICT & 0.25 & Sometimes \\
\hline 16. & $\begin{array}{l}\text { I train students to discuss and explore the } \\
\text { concept of mathematics through ICT }\end{array}$ & 0.60 & Rarely \\
\hline 17. & ICT gives me other ways of teaching math & -0.89 & Always \\
\hline 18. & $\begin{array}{l}\text { I give students the chance to search for } \\
\text { information using ICT }\end{array}$ & -0.38 & Mostly \\
\hline 19. & $\begin{array}{l}\text { I use social media in exchanging mathematics } \\
\text { teaching strategies with my colleagues }\end{array}$ & -0.62 & Mostly \\
\hline
\end{tabular}

The value distribution in general of the perception of mathematics teachers in the marginal area towards the use of ICT media in Figure 1 shows that by using ICT the way of teachers teaching became more varied and not monotonous.

The distribution of data based on school levels shows that those who have high perceptions of ICT are found in junior high schools (P) by $61.54 \%$ of a total of 13 people. At the most moderate perception, there is $54.55 \%$ of the total of 44 people in junior high school (A). Whereas, the lowest perception is at elementary school (D) level that is $48.15 \%$ of 27 teachers, as shown in Table 7.

Table 7. Perception of the use of ICT based on School Level

\begin{tabular}{cccccc}
\hline \multirow{2}{*}{ Category } & \multicolumn{3}{c}{ Level } & \multicolumn{2}{c}{ Total } \\
\cline { 2 - 5 } & D & P & A & & $15.48 \%$ \\
\hline High & 4 & 8 & 1 & 13 & $52.38 \%$ \\
Medium & 12 & 24 & 8 & 44 & $32.14 \%$ \\
Low & 13 & 9 & 5 & 27 & $100.00 \%$ \\
\hline Total & 29 & 41 & 14 & 84 & \\
\hline
\end{tabular}

The perception of mathematics teachers in the marginal area towards the use of ICT media based on geographical location is that those who have a high perception are located 
in western Indonesia (W) by $69.23 \%$. Likewise, for medium and low perception is also the case in by western Indonesia (W) by $61.36 \%$ and $51.85 \%$. This can be seen in Table 8 .

Table 8. Perceptions of The Use of ICT based on Geographical Location

\begin{tabular}{ccccc}
\hline \multirow{2}{*}{ Category } & \multicolumn{3}{c}{ Location } & \multicolumn{2}{c}{ Total } \\
\cline { 2 - 4 } & $\mathbf{E}$ & $\mathbf{W}$ & & 13 \\
\hline High & 4 & 9 & & $13.48 \%$ \\
Medium & 17 & 27 & 44 & $52.38 \%$ \\
Low & 13 & 14 & 27 & $32.14 \%$ \\
\hline Total & 34 & 50 & 84 & $100.00 \%$ \\
\hline
\end{tabular}

The perception of mathematics teachers in the marginal area towards the use of ICT media based on school levels and geographical location (see Table 9) illustrates that high perceptions were found in junior high schools (P) in western Indonesia (W) by $38.46 \%$ of respondents. The medium perception category lies in junior high school (P) level in eastern Indonesia (E) by $34.09 \%$. Whereas for the low category owned by elementary school (D) respondents in western Indonesia (W) as much as $40.74 \%$.

Table 9. Perception of the use of ICT based on school level and geographical location

\begin{tabular}{|c|c|c|c|c|c|c|c|c|}
\hline \multirow{2}{*}{ Category } & \multicolumn{2}{|c|}{ D } & \multicolumn{2}{|c|}{$\mathbf{P}$} & \multicolumn{2}{|c|}{$\mathbf{A}$} & \multirow{2}{*}{\multicolumn{2}{|c|}{ Total }} \\
\hline & $\mathbf{E}$ & $\mathbf{W}$ & $\mathbf{E}$ & $\mathbf{W}$ & $\mathbf{E}$ & $\mathbf{W}$ & & \\
\hline High & 0 & 4 & 3 & 5 & 1 & 0 & 13 & $15.48 \%$ \\
\hline Medium & 0 & 12 & 15 & 9 & 2 & 6 & 44 & $52.38 \%$ \\
\hline Low & 2 & 11 & 6 & 3 & 5 & 0 & 27 & $32.14 \%$ \\
\hline Total & 2 & 27 & 24 & 17 & 8 & 6 & 84 & $100.00 \%$ \\
\hline
\end{tabular}

\subsubsection{The importance of ICT as a learning media}

Questionnaire data distribution consisted of 27 items of statements regarding the importance of using ICT as a learning medium, and there were 84 respondents of mathematics teachers in the marginal regions ranging from elementary school (D), junior high school (P) and high school (A) scattered from western Indonesia (W) to Eastern Indonesia (E). The variable map in Figure 2 shows that the items that are most difficult to be agreed upon by respondents are items number 17 and 2 . In contrast, item that is highly approved is item number 9 . 


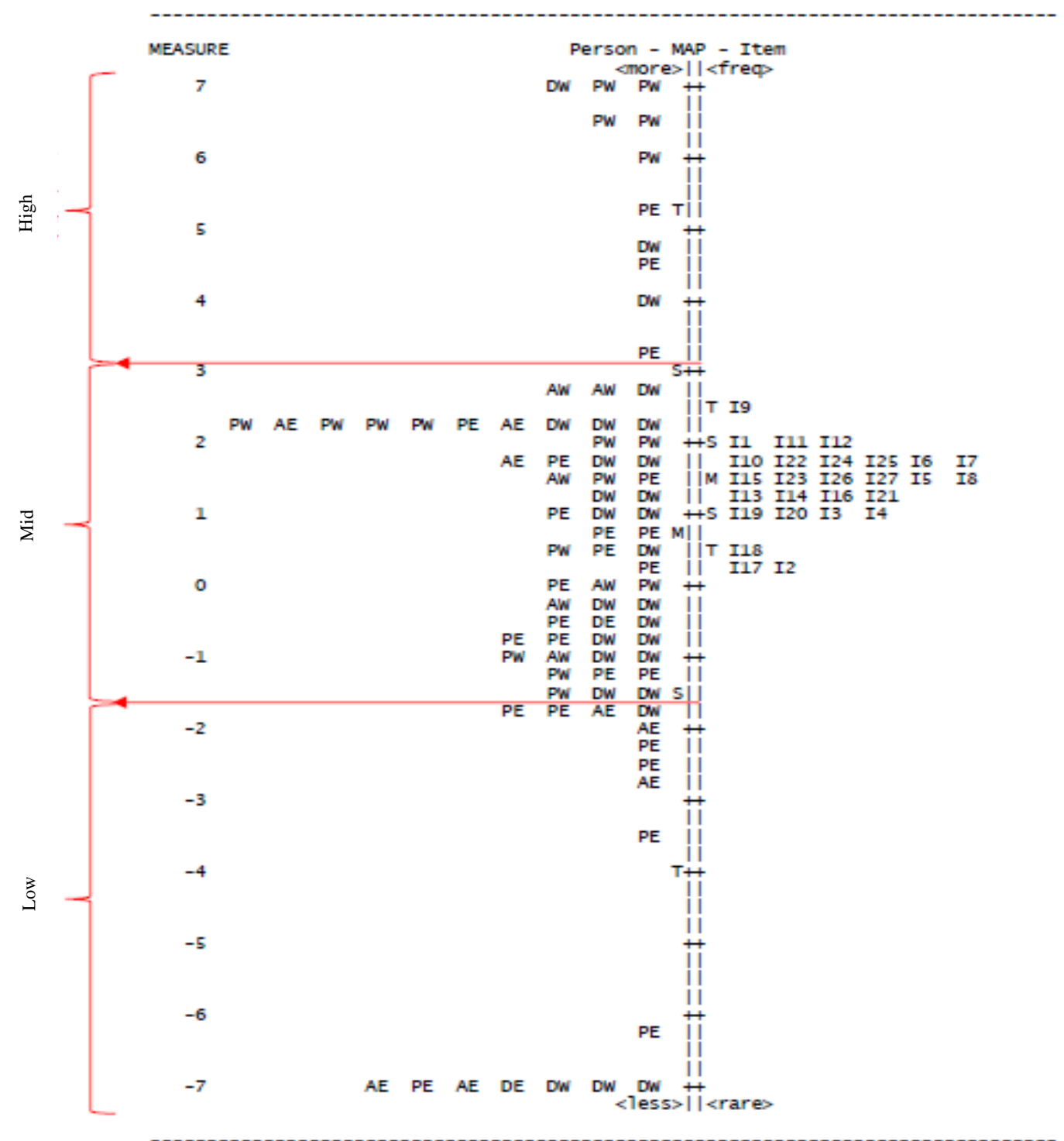

Figure 2. Variable map the importance of ICT as a learning media

While Table 10 shows the standard logit deviation values according to the item logit category of respondents' responses in Table 1. From Table 10, it is known that there are three items in the 'unimportant' category (No. 2,17 and 18). While the category of usage is 'very important' there is 1 item (No. 9). In addition, it can be seen that there are 15 items that are categorised as 'fairly important' and 'somewhat important' and nine items that are 'important' and 'very important'.

Table 10. Domain 2: The importance of using ICT as a learning media

\begin{tabular}{clcc}
\hline No & \multicolumn{1}{c}{ Items } & Logit Value & Most Responses \\
\hline 1 & I use ICT in teaching math & -0.67 & Important \\
2 & $\begin{array}{l}\text { I give students my social media contact } \\
\text { information at the beginning of the semester }\end{array}$ & 1.09 & Unimportant \\
3 & $\begin{array}{l}\text { I encourage students to use ICT more than the } \\
\text { other ways }\end{array}$ & 0.44 & Fairly Important \\
\hline
\end{tabular}




\begin{tabular}{|c|c|c|c|}
\hline No & Items & Logit Value & Most Responses \\
\hline 4 & $\begin{array}{l}\text { ICT makes it easy for students to communicate } \\
\text { within groups }\end{array}$ & 0.31 & Fairly Important \\
\hline 5 & $\begin{array}{l}\text { I give students an idea about necessary apps and } \\
\text { math learning website }\end{array}$ & -0.04 & Somewhat Important \\
\hline 6 & $\begin{array}{l}\text { Some students advance/improve because of their } \\
\text { use of ICT }\end{array}$ & -0.22 & Somewhat Important \\
\hline 7 & $\begin{array}{l}\text { ICT is important for students' learning } \\
\text { advancement/improvement }\end{array}$ & -0.33 & Important \\
\hline 8 & $\begin{array}{l}\text { I encourage students to seek inspiration when } \\
\text { they used ICT }\end{array}$ & -0.15 & Somewhat Important \\
\hline 9 & Using ICT makes learning to be more amusing & -0.99 & Very Important \\
\hline 10 & $\begin{array}{l}\text { Using ICT helps to build students' collaborative } \\
\text { methods and skills }\end{array}$ & -0.36 & Important \\
\hline 11 & $\begin{array}{l}\text { ICT helps students by delivering the content of } \\
\text { math's courses }\end{array}$ & -0.55 & Important \\
\hline 12 & $\begin{array}{l}\text { ICT helps me to facilitate the presentation of } \\
\text { information }\end{array}$ & -0.67 & Important \\
\hline 13 & $\begin{array}{l}\text { ICT helps in considering individual differences } \\
\text { among students }\end{array}$ & 0.17 & Somewhat Important \\
\hline 14 & $\begin{array}{l}\text { ICT gives students the chance to cooperate in } \\
\text { learning }\end{array}$ & 0.14 & Somewhat Important \\
\hline 15 & $\begin{array}{l}\text { ICT gives me a chance to solve students' } \\
\text { problems about learning mathematics }\end{array}$ & -0.04 & Somewhat Important \\
\hline 16 & I teach the content of some courses through ICT & 0.07 & Somewhat Important \\
\hline 17 & $\begin{array}{l}\text { I give students extracurricular activities through } \\
\text { ICT }\end{array}$ & 1.09 & Unimportant \\
\hline 18 & $\begin{array}{l}\text { I assign students in groups to discuss and solve } \\
\text { mathematics problems through ICT }\end{array}$ & 0.90 & Unimportant \\
\hline 19 & $\begin{array}{l}\text { ICT helps me in preparing quizzes and } \\
\text { conducting them through ICT }\end{array}$ & 0.54 & Fairly Important \\
\hline 20 & I designed the math course using ICT & 0.38 & Fairly Important \\
\hline 21 & Using ICT helps students gain more confidence & 0.07 & Somewhat Important \\
\hline 22 & $\begin{array}{l}\text { Using ICT gives students important life } \\
\text { experiences }\end{array}$ & -0.36 & Important \\
\hline 23 & $\begin{array}{l}\text { Using ICT equips students with the skills for } \\
\text { discussion and debate }\end{array}$ & -0.07 & Somewhat Important \\
\hline 24 & ICT equips students with the skill of self-learning & -0.25 & Important \\
\hline 25 & $\begin{array}{l}\text { ICT helps in creating a variety in math-teaching } \\
\text { methods }\end{array}$ & -0.33 & Important \\
\hline 26 & ICT pushes students to learn & -0.18 & Somewhat Important \\
\hline 27 & ICT helps students gain social skills & 0.03 & Somewhat Important \\
\hline
\end{tabular}

Based on responses shown in Table 10, it can be seen that the teachers mostly agree that ICT plays an important role to make the learning process to be more interesting and enjoyable for students. 
The distribution of data based on school levels shows that those who have a high perception of the importance of using ICT as a learning media are found at the junior high school level (P) by $72.73 \%$ of a total of 11 people. At the most moderate perception, it has at the junior high school level (P) $46.43 \%$ of the total of 56 people. Likewise, the lowest level of perception was in junior high school level (P), namely $41.18 \%$ of 17 people, as shown in Table 11.

Table 11. Perceptions of the importance of ICT based on school

\begin{tabular}{cccccc}
\hline \multirow{2}{*}{ Category } & \multicolumn{3}{c}{ Level } & \multicolumn{2}{c}{ Total } \\
\cline { 2 - 4 } & D & P & A & & $13.10 \%$ \\
High & 3 & 8 & 0 & 11 & $66.67 \%$ \\
Medium & 21 & 26 & 9 & 56 & $20.24 \%$ \\
Low & 5 & 7 & 5 & 17 & $100.00 \%$ \\
\hline Total & 29 & 41 & 14 & 84 & \\
\hline
\end{tabular}

The perception of mathematics teachers in the marginal area towards the importance of ICT media based on geographical location is that those who have a high perception are located in western Indonesia (W) by $72.73 \%$. Likewise, for moderate perception found in western Indonesia (W) which is $67.86 \%$. Whereas in the low perception owned by eastern Indonesia (E) was 76.47\%. This can be seen in Table 12 .

Table 12. Perceptions of the importance of ICT based on geographical location

\begin{tabular}{ccccccc}
\hline \multirow{2}{*}{ Category } & \multicolumn{3}{c}{ Location } & \multicolumn{2}{c}{ Total } \\
\cline { 2 - 5 } & \multicolumn{3}{c}{$\mathbf{E}$} & \multicolumn{2}{c}{$\mathbf{W}$} & \multicolumn{2}{c}{} \\
\cline { 2 - 5 } & $\mathbf{( N )}$ & $(\boldsymbol{\%})$ & $\mathbf{( N )}$ & $\mathbf{( \% )}$ & $\mathbf{( N )}$ & $(\boldsymbol{\%})$ \\
\hline High & 3 & $27.27 \%$ & 8 & $72.73 \%$ & 11 & $13.10 \%$ \\
Medium & 18 & $32.14 \%$ & 38 & $67.86 \%$ & 56 & $66.67 \%$ \\
Low & 13 & $76.47 \%$ & 4 & $23.53 \%$ & 17 & $20.24 \%$ \\
\hline Total & 34 & $100.00 \%$ & 50 & $100.00 \%$ & 84 & $100.00 \%$ \\
\hline
\end{tabular}

Mathematics teachers' perception in the marginal area on the importance of ICT media based on education level and geographical location as seen in Table 13 illustrates that high perceptions were found in junior high schools in western Indonesia by $45.45 \%$. On the perception at the elementary school level in western Indonesia by $35.71 \%$. Whereas for low perception, there is a junior high school level in eastern Indonesia that is $41.18 \%$.

Table 13. Perceptions of the importance of ICT based on education level and geographical location

\begin{tabular}{ccccccccc}
\hline \multirow{2}{*}{ Category } & \multicolumn{2}{c}{ D } & \multicolumn{2}{c}{ P } & \multicolumn{2}{c}{ A } & \multirow{2}{*}{ Total } \\
\cline { 2 - 6 } & $\mathbf{E}$ & $\mathbf{W}$ & $\mathbf{E}$ & $\mathbf{W}$ & $\mathbf{E}$ & $\mathbf{W}$ & & \\
\hline High & 0 & 3 & 3 & 5 & 0 & 0 & 11 & $13.10 \%$ \\
Medium & 1 & 20 & 14 & 12 & 3 & 6 & 56 & $66.67 \%$ \\
Low & 1 & 4 & 7 & 0 & 5 & 0 & 17 & $20.24 \%$ \\
\hline Total & 2 & 27 & 24 & 17 & 8 & 6 & 84 & $100.00 \%$ \\
\hline
\end{tabular}




\subsection{Discussion}

This study found that the majority of marginal regions mathematics teachers are not using any ICT or even digital media during teaching mathematics. The constraint of facility and communication access are common limitations in marginal regions (Kementerian PPN/Bappenas, 2016). This can be understood by looking at the situation in the regions that many mathematics teachers do not utilise ICT in mathematics classrooms. In addition, a study by Perbowo, Maarif, and Pratiwi (2019) shows that the perception of marginal regions mathematics teachers on the use of manipulative tools is higher than on the use of ICT.

Most marginal region mathematics teachers are choosing Microsoft Office to help their teaching since Microsoft holds the biggest office software market over the globe (Gandal, Markovich, \& Riordan, 2018); obviously, Microsoft Office software becomes the most common bundle for a personal computer or laptop unit and does not require internet access to be operated. This software is sometimes considered as the standard software for the requirements for successful e-learning (Waterhouse \& Rogers, 2004).

In line with Lawrence and Tar (2018), the utilisation of ICT provides more opportunities for teachers to improve the quality of teaching and learning environment. In addition, the findings show that the teachers would promote the use of ICT to students to help them learn mathematics.

The use of ICT media as a medium of mathematics learning is dominated by western Indonesia because there has been more developement and improvement for the access of the community to ICT, compared to eastern Indonesia, especially in Garut district and Riau Province (Djuwendah, Hapsari, Renaldy, \& Saidah, 2013; Syahza \& Suarman, 2013). According to Tossavainen and Faarinen (2019), ICT adds more positive value in mathematics classroom while traditional teaching of mathematics is more or less boring. On the contrary, teachers tend to mind giving students their social media contact information. They see this as an unimportant matter in mathematics teaching and learning. In addition, teachers also assume that giving extra activities for students to discuss and doing mathematical activities through ICT as another unimportant case. Teachers must be aware that ICT not only can increase student motivation (Tossavainen \& Faarinen, 2019), but also can enhance students' understanding and mathematics proficiency (Drijvers, Boon, \& Van Reeuwijk, 2011; Widodo et al., 2019).

The rapid development of digital media, especially ICT, is affecting the way in which humans live and learn (Voogt \& Roblin, 2012). Mathematics teachers, especially in marginal regions, need to continuously transform and adapt in order to comply with the competencies needed for industrial revolution 4.0 in the 21 st century. The findings of this study show that marginal regions mathematics teachers do not have a high perception of adopting ICT in their teaching. In addition, they do not have enough concerns about the role of ICT in promoting students' performance and proficiency in mathematics. We assume that it is because of all barriers and limitations they face in their region. Yet, they must be able to deal with the situation.

The challenge for the future is to give a handful of designs to teach mathematics in marginal regions; a design that can optimise the learning environment within the regions. Thus, further studies for teaching and learning designs that are suitable in marginal regions are needed; whether it involves digital media, hands-on manipulative tools or any media that can help teachers to teach mathematics as concrete as possible. Thus, at least there are two factors that needed to be considered in order to create the most suitable teaching design for mathematics classrooms in marginal regions which are learning environment and realistic mathematics context. 


\section{CONCLUSION}

The study findings indicate that most marginal regions mathematics teachers are still not utilising ICT or any other digital media in their teaching. Most teachers who use ICT are using Microsoft Media since this software is common and does not require internet access to be operated. In specific, online media is mostly used in teaching mathematics for primary school, while mathematics software for secondary school and Microsoft Office for senior high school. The perception of mathematics teachers in the marginal regions towards the domain of the use of ICT can be categorised as 'medium' which is dominated by secondary school mathematics teachers in marginal regions of eastern Indonesia. The teachers are used to adopting ICT in teaching mathematics regularly. In comparison, the perception of mathematics teachers in the marginal area on the importance of ICT can be categorised as 'medium' which is dominated by elementary mathematics teachers in the marginal region of western Indonesia. Teachers assume it is just fairly-important for ICT media to be used in mathematics teaching and learning. Based on this research it was found that the perception of mathematics teachers in the marginal area towards the importance of ICT media in mathematics teaching and learning is in the category of 'medium' and responses in both domains were dominated by 'sometimes', that is the marginal regional mathematics teachers assumed non-ICT normal and only performed some activities learning mathematics with ICT media.

\section{REFERENCES}

Afidah, A. N., Doom, M., \& Putri, R. N. S. (2017). Laporan Kinerja Kementerian Komunikasi dan Informatika Tahun 2017. Jakarta: Kementerian Komunikasi dan Informatika Republik Indonesia.

Ahern, T. C. (2016). A waterfall design strategy for using social media for instruction. Journal of Educational Technology Systems, 44(3), 332-345. https://doi.org/10.1177/0047239515615853

Albalaw, A. S. (2017). Mathematics teachers' perception of using social media in their teaching in Tabuk, Saudi Arabia. International Electronic Journal of Mathematics Education, 12(2), 111-131.

Alghamdi, I., Goodwin, R., \& Rampersad, G. (2011). E-government readiness assessment for government organisations in developing countries. Computer and Information Science, 4(3), 3-17. https://doi.org/10.5539/cis.v4n3p3

Ali, G., Haolader, F. A., \& Muhammad, K. (2013). The role of ICT to make teachinglearning effective in higher institutions of learning in Uganda. International Journal of Innovative Research in Science, Engineering and Technology, 2(8), 4061-4073.

Amin, M. (2016). Akses dan penggunaan internet pitalebar di wilayah perbatasan (Indonesia-Papua Nugini dan Indonesia-Timor Leste). Jurnal Ilmu Pengetahuan dan Teknologi Komunikasi, 18(1), 35-50.

Bakar, K. A., Ayub, A. F. M., \& Tarmizi, R. A. (2010). Exploring the effectiveness of using GeoGebra and e-transformation in teaching and learning Mathematics. Proc. of Intl. Conf. of Advanced Educational Technologies EDUTE, 2, 19-23.

Blum, C., \& Parette, H. P. (2015). Universal design for learning and technology in the early childhood classroom. In Young children and families in the information age, 165182. Dordrecht: Springer. https://doi.org/10.1007/978-94-017-9184-7_10 
Bond, T., Yan, Z., \& Heene, M. (2020). Applying the Rasch model: Fundamental measurement in the human sciences. New York: Routledge. https://doi.org/10.4324/9780429030499

Bush, W. S. (2005). Improving research on mathematics learning and teaching in rural contexts. Journal of Research in Rural Education, 20(8), 1-11.

Chaerul, M., \& Aisyah, S. (2014). Implikasi corporate social responsibility (CSR) melaui entrepreneur school di daerah tertinggal berbasis 3E (education, entrepreneurship, environment) menuju millennium development goals (MDGS) 2015. Jurnal PENA: Penelitian dan Penalaran, 1(1), 31-41.

Djuwendah, E., Hapsari, H., Renaldy, E., \& Saidah, Z. (2013). Strategi pengembangan daerah tertinggal di Kabupaten Garut. Sosiohumaniora, 15(2), 167-177.

Donnelly, D., McGarr, O., \& O'Reilly, J. (2011). A framework for teachers' integration of ICT into their classroom practice. Computers \& Education, 57(2), 1469-1483. https://doi.org/10.1016/j.compedu.2011.02.014

Drijvers, P., Boon, P., \& Van Reeuwijk, M. (2011). Algebra and technology. In Secondary Algebra Education, 179-202. Rotterdam: Sense Publishers. https://doi.org/10.1007/978-94-6091-334-1_8

Eyyam, R., \& Yaratan, H. S. (2014). Impact of use of technology in mathematics lessons on student achievement and attitudes. Social Behavior and Personality: an international journal, 42(1), 31S-42S. https://doi.org/10.2224/sbp.2014.s31

Gandal, N., Markovich, S., \& Riordan, M. H. (2018). Ain't it "suite"? Bundling in the PC office software market. Strategic Management Journal,39(8), 2120-2151. https://doi.org/10.1002/smj.2797

Gautam, K. K., \& Agrawal, P. C. (2012). Impact and utilization of projectors in higher education with low energy consumption and last long batties in WSN environment. International Journal of Computer Science \& Engineering Technology, 3(9), 449-455.

Hismanoglu, M. (2012). Prospective EFL teachers' perceptions of ICT integration: A study of distance higher education in Turkey. Journal of Educational Technology \& Society, 15(1), 185-196.

Howley, C. B., Howley, A. A., \& Huber, D. S. (2005). Prescriptions for rural mathematics instruction: Analysis of the rhetorical literature. Journal of Research in Rural Education, 20(7), 1-16.

Kementerian PPN/Bappenas. (2016). Koordinasi strategis percepatan pelaksanaan program pembangunan daerah tertinggal untuk mendukung PP no. 78 tahun 2014 dan Perpres No. 131 tahun 2015. Jakarta: Kementerian PPN/Bappenas.

Koesnandar, A. (2013). Pengembangan Model Pendayagunaan Teknologi Informasi Dan Komunikasi (Tik) Untuk Pendidikan Di Daerah Terpencil, Tertinggal, Dan Terdepan. Kwangsan: Jurnal Teknologi Pendidikan, 1(2), 122-142. https://doi.org/10.31800/jtp.kw.v1n2.p122--142

Lawrence, J. E., \& Tar, U. A. (2018). Factors that influence teachers' adoption and integration of ICT in teaching/learning process. Educational Media International, 55(1), 79-105. https://doi.org/10.1080/09523987.2018.1439712 
Limayem, M., \& Cheung, C. M. (2011). Predicting the continued use of Internet-based learning technologies: the role of habit. Behaviour \& Information Technology, 30(1), 91-99. https://doi.org/10.1080/0144929X.2010.490956

Lin, J. M. C., Wang, P. Y., \& Lin, I. C. (2012). Pedagogy* technology: A two-dimensional model for teachers' ICT integration. British Journal of Educational Technology, 43(1), 97-108. https://doi.org/10.1111/j.1467-8535.2010.01159.x

Linacre, J. M. (2011). A user's guide to winsteps ministeps: Rasch-model computer program. Oregon: Winsteps.com.

Muhson, A. (2010). Pengembangan media pembelajaran berbasis teknologi informasi. Jurnal Pendidikan Akuntansi Indonesia, 8(2), 1-10. https://doi.org/10.21831/jpai.v8i2.949

Nicol, C., Archibald, J. A., \& Baker, J. (2013). Designing a model of culturally responsive mathematics education: Place, relationships and storywork. Mathematics Education Research Journal, 25(1), 73-89. https://doi.org/10.1007/s13394-012-0062-3

Nurseto, T. (2011). Membuat media pembelajaran yang menarik. Jurnal Ekonomi dan pendidikan, 8(1), 19-35. https://doi.org/10.21831/jep.v8i1.706

Perbowo, K. S., Maarif, S., \& Pratiwi, A. (2019). Perception of mathematics teachers in marginal regions toward the use of ICT and manipulative tools as learning media. Journal of Physics: Conference Series, 1315(1), 012042. https://doi.org/10.1088/1742-6596/1315/1/012042

Safitri, M., Hartono, Y., \& Somakim, S. (2013). Pengembangan media pembelajaran matematika pokok bahasan segitiga menggunakan macromedia flash untuk siswa kelas VII SMP. Jurnal $\quad$ Pendidikan, 14(2), 62-72. https://doi.org/10.33830/jp.v14i2.358.2013

Smith, R. C., Shin, D., \& Kim, S. (2017). Prospective and current secondary mathematics teachers' criteria for evaluating mathematical cognitive technologies. International Journal of Mathematical Education in Science and Technology, 48(5), 659-681. https://doi.org/10.1080/0020739X.2016.1264635

Sumintono, B., \& Widhiarso, W. (2014). Aplikasi model Rasch untuk penelitian ilmu-ilmu sosial (edisi revisi). Cimahi: Trim Komunikata Publishing House.

Syahza, A., \& Suarman. (2013). Strategi pengembangan daerah tertinggal dalam upaya percepatan pembangunan ekonomi pedesaan. Jurnal Ekonomi Pembangunan, 14(1), 126-139. https://doi.org/10.23917/jep.v14i1.166

Tim Indikator TIK Pusat Litbang PPI. (2015). Hasil survei indikator TIK 2015 rumah tangga dan individu. Jakarta: Badan Litbang SDM Kementerian Komunikasi dan Informatika.

Tossavainen, T., \& Faarinen, E. C. (2019). Swedish Fifth and Sixth Graders' Motivational Values and the Use of ICT in Mathematics Education. EURASIA Journal of Mathematics, Science and Technology Education, 15(12), em1776. https://doi.org/10.29333/ejmste/108533

Triyanto, E., Anitah, S., \& Suryani, N. (2013). Peran kepemimpinan kepala sekolah dalam pemanfaatan media pembelajaran sebagai upaya peningkatan kualitas proses pembelajaran. Jurnal Teknologi Pendidikan, 1(2), 226-238. 
Voogt, J., \& Roblin, N. P. (2012). A comparative analysis of international frameworks for 21st century competences: Implications for national curriculum policies. Journal of curriculum studies, 44(3), 299-321. https://doi.org/10.1080/00220272.2012.668938

Waterhouse, S., \& Rogers, R. O. (2004). The importance of policies in e-learning instruction. Educause quarterly, 27(3), 28-39.

Widodo, S., Irfan, M., Leonard, L., Fitriyani, H., Perbowo, K., \& Trisniawati, T. (2019). Visual Media in Team Accelerated Instruction to Improve Mathematical ProblemSolving Skill. In Proceedings of the 1st International Conference on Science and Technology for an Internet of Things. European Alliance for Innovation (EAI). http://doi.org/10.4108/eai.19-10-2018.2281297 